\title{
Presence of autocrine hepatocyte growth factor-Met signaling and its role in proliferation and migration of SNU-484 gastric cancer cell line
}

\author{
Minseon Park ${ }^{1,3}$, Hyelee Park ${ }^{2}$, \\ Wook-Hwan Kim ${ }^{2,3}$, Hyeseong $\mathrm{Cho}^{1,3}$ \\ and Jae-Ho Lee Let, $^{1,3}$ \\ ${ }^{1}$ Department of Biochemistry \\ ${ }^{2}$ Department of General Surgery \\ ${ }^{3}$ Chronic Inflammatory Disease Research Center \\ Ajou University Medical School \\ San 5 Wonchon-dong, Yeongtong-gu \\ Suwon 443-721, Korea \\ ${ }^{4}$ Corresponding author: Tel, 82-31-219-5053; \\ Fax, 82-31-219-5059; E-mail, jhlee64@ajou.ac.kr
}

Accepted 31 May 2005

Abbreviations: ELISA, enzyme-linked immunosorbent assay; HGF, hepatocyte growth factor; RT-PCR, reverse transcription polymerase chain reaction

\begin{abstract}
Autocrine stimulation via coexpression of hepatocyte growth factor (HGF) and its receptor (Met) has been reported in many human sarcomas, but few in carcinomas. In this report, we found that one gastric cancer cell line, SNU-484, among 11 gastric cell lines tested has an autocrine HGF. Met stimulation. RT-PCR, ELISA and scattering assay using MDCK cells revealed that SNU-484 cells secreted a significant amount of active HGF (about $1.25 \pm 0.41 \mathrm{ng} / 24 \mathrm{~h} / 10^{6}$ cells) into conditioned medium. Resultantly, Met in this cell line was constitutively phosphorylated. Neutralizing antibodies against HGF reduced the tyrosine phosphorylation of Met, resulting in the inhibition of cell proliferation and migration $(P<0.005)$. To the best of our knowledge, this is the first report on autocrine HGF-Met signaling in a gastric cancer cell line. Our observations with SNU-484 cells suggest that HGF is involved in the development and/or progression of some gastric carcinoma through an autocrine mechanism.
\end{abstract}

Keywords: autocrine; gastric cancer; hepatocyte growth factor; Met; migration; proliferation

\section{Introduction}

The proto-oncogene c-met encodes a $190 \mathrm{kDa}$ heterodimeric transmembrane tyrosine kinase which has been identified as the receptor of hepatocyte growth factor (HGF, also known as scatter factor) (Bottaro et al., 1991). Binding with HGF triggers tyrosine autophosphorylation of the intracellular domain of Met and induces pleiotropic responses such as proliferation, motility, morphogenesis, and angiogenesis in many types of cells including various tumor cells (reviewed in Stella and Comoglio, 1999). HGF is expressed in mesenchymally derived cells, while Met expression has been detected in the epithelium of most tissues, indicating that HGF-Met signal transduction pathway is involved in mesenchymal-epithelial interactions (Rubin et al., 1991; Rosen et al., 1994). Although HGF acts mainly in paracrine manner, co-expression of HGF and the Met receptor also has been detected in a variety of human tumors; mostly sarcomas and a few carcinoma cases including breast (Jin et al., 1997), pancreatic (Ebert et al., 1999), ovarian cancers (Wong et al., 2001), glioblastoma (Shiota et al., 1996), and melanoma (Otsuka et al., 1998). Moreover, invasive and metastatic progression of cells having experimental HGF-Met autocrine loop suggests that autocrine activation of Met may be closely associated with progression of tumor cells (Rong et al., 1994; Otsuka et al., 1998).

Gastric carcinoma is one of the most common and lethal malignant tumors. In the stomach, whereas low or undetectable levels of Met mRNA are found in normal mucosa, much higher level of mRNA has been observed in their malignant counterpart (Di Renzo et al., 1991; Kaji et al., 1996), suggesting involvement of HGF signaling in gastric cancer formation and/or progression. In addition, it has been reported that HGF level in serum or tumor tissue was highly elevated in gastric cancer patients (Han et al., 1998), and that the increase of serum HGF level was significantly correlated with the progression of tumor stage (Han et al., 1999). Taken together, these results strongly suggest that the Met overexpression and the paracrine interaction of HGF with Met may play an important role in the tumorigenesis and progression of gastric carcinoma.

Although there are a few reports suggesting possible involvement of HGF-Met autocrine signaling in gastric tumorigenesis (Fushida et al.,1993; Park et al., 2000), no study actually showed the presence of autocrine HGF-Met pathway in gastric cancer cells. In this study, we demonstrated the presence of HGF-Met autocrine signaling in a gastric cancer cell line and its role in the proliferation and migration 
of gastric cancer cells.

\section{Materials and Methods}

\section{Antibodies and reagents}

Rabbit polyclonal anti-Met antibody (C-28) was obtained from Santa Cruz Biotechnology (Santa Cruz, CA), and rabbit polyclonal anti-phospho (Tyr1234/ 1235) Met antibody was from Cell Signaling Technology (Beverly, MA). Mouse monoclonal anti-phosphotyrosine (PY20) antibody was obtained from Zymed Laboratories Inc. (South San Francisco, CA). Rabbit polyclonal phopho-p44/p42 MAP kinase antibody and rabbit polyclonal p44/p42 MAP kinase antibody were purchased from Cell Signaling Technology. Neutralizing goat anti-human HGF antibody was obtained from R\&D Systems, Inc. (Minneapolis, MN). Recombinant human hepatocyte growth factor (rhHGF) was generously provided by Dr. G. Vande Woude (Laboratory of Molecular Oncology, Van Andel Research Institute, Grand Rapids, MI). HGF concentrations are presented as scatter units $(U) / \mathrm{ml}$; and $5 \mathrm{U}$ are equivalent to approximately $1 \mathrm{ng}$ of protein. Culture reagents were obtained from Gibco BRL (Carlsbad, CA). Protease inhibitor cocktail tablet was purchased from Roche Applied Science (Mannheim, Germany). Phosphatase inhibitors and other reagents not specified were from Sigma Chemical Co. (St. Louis, MO).

\section{Cell culture}

The human gastric adenocarcinoma cell lines were purchased from Korean Cell Line Bank (Seoul, Korea), except AGS cell line, which was purchased from American Type Culture Collection (Rockville, MD). The cells were grown in RPMI-1640 medium supplemented with $10 \%$ heat-inactivated fetal bovine serum (FBS). Cultures were maintained in a humidified incubator at $37^{\circ} \mathrm{C}$ in normal atmosphere containing $5 \%$ $\mathrm{CO}_{2}$.

\section{Cell proliferation assay}

To examine the effect of secreted HGF on cell growth, MTT assay was performed with Cell Proliferation Kit I [MTT; 3-(4,5-dimethylthiazol-2-yl)-2,5-diphenyl tetrazolium bromide] by following the manufacturer's instruction (Roche Applied Science). SNU-484 cells were seeded at a density of $10^{4}$ cells/well into 96-well plate in RPMI-1640 supplement with 10\% FBS. After overnight incubation, medium was changed into RPMI1640 containing $0.1 \%$ FBS with various concentrations of neutralizing anti-HGF antibody, and MTT assay was performed at the indicated time points.

\section{RT-PCR}

Total RNA was extracted from subconfluent cells by using TRIzol ${ }^{\mathbb{R}}$ Reagent (Invitrogen Co., Carlsbad,
CA). Concentration and purity of RNA samples were assessed by measuring absorbance at $260 \mathrm{~nm}$ and $280 \mathrm{~nm}$. For first strand synthesis, total RNA $(1 \mu \mathrm{g})$ was dissolved in $4 \mu \mathrm{l}$ of water, heated to $70^{\circ} \mathrm{C}$ for $5 \mathrm{~min}$, and then chilled on ice. The volume was increased to $20 \mu \mathrm{l}$, giving a final concentration of 0.25 $\mathrm{nM}$ each of dNTPs, 5 pmoles of oligo $(\mathrm{dT})_{15} / \mu \mathrm{l}, 1 \mathrm{U} / \mu \mathrm{l}$ of RNase inhibitor, $200 \mathrm{U} / \mathrm{ml}$ of AMV Reverse Transcriptase XL (TAKARA Bio Inc., Japan). For the amplification of hgf gene, $3 \mu \mathrm{l}$ of CDNA was subjected to PCR and amplified with both sense (5'-CCATG AATTTGACCTCTATG-3') and antisense primers (5'AACTCGGATGTTTGGATCA-3') for 30 cycles by incubation at $94^{\circ} \mathrm{C}$ for $45 \mathrm{~s}, 65^{\circ} \mathrm{C}$ for $1 \mathrm{~min}$, and $72^{\circ} \mathrm{C}$ for $1 \mathrm{~min}$ in a PCR9600 thermocycler (Perkin-Elmer, Corona, CA). One fifth of PCR products was then subjected to electrophoresis on $1.2 \%$ agarose gels and stained with ethidium bromide.

\section{Determination of HGF level}

The amount of HGF secreted from SNU-484 was determined by using IMMUNIS HGF EIA kit (Institute of Immunology, Tokyo, Japan) according to the manufacturer's instruction.

\section{Mardin-Darby canine kidney (MDCK) cell scattering assay}

SNU-484 cells were grown to confluence, washed with phosphate-buffered saline (PBS), and further cultured in serum-free RPMI-1640 for $24 \mathrm{~h}$. The supernatant was collected, clarified, and concentrated 8 fold by using Centriplus ${ }^{\circledR}$ Centrifugal Filter Devices (Millipore Co., Bedford, MA). The presence of active HGF in the conditioned medium was determined by MDCK cell scattering assay (Stoker and Perryman, 1985). Briefly, the concentrated conditioned medium was serially diluted with $10 \%$ FBS-containing DMEM and added to MDCK cells in a 96 -well plate $\left(2 \times 10^{3}\right.$ cells/well). Cells were incubated for $24 \mathrm{~h}$, then fixed in acetone: methanol $(1: 1, \mathrm{v} / \mathrm{v})$ for $15 \mathrm{~min}$ on ice and stained with $2 \%$ crystal violet. Scattering of the cells was observed under light microscope.

\section{Immunoprecipitation and Western blotting}

Cells were lysed in RIPA buffer $(50 \mathrm{mM}$ Tris- $\mathrm{HCl}, \mathrm{pH}$ $7.4,1 \%$ NP-40, $0.1 \%$ SDS, $150 \mathrm{mM} \mathrm{NaCl}, 5 \mathrm{mM}$ EDTA) containing freshly added protease inhibitor cocktail solution (Roche) and/or phosphatase inhibitors (1 $\mathrm{mM}$ sodium fluoride, $1 \mathrm{mM}$ sodium orthovanadate). Cell lysates (1 $\mathrm{mg}$ of protein) were incubated with $1 \mathrm{\mu g}$ of anti-Met antibody (C-28) for 16 $\mathrm{h}$ at $4^{\circ} \mathrm{C}$ with gentle rotation. Twenty microliters of $50 \%$ slurry of rProtein G Agarose (Invitrogen) were added, and the mixture was further incubated for an hour. Following three washes in lysis buffer, the immunoprecipitates were resolved by $8 \%$ SDS-PAGE and transferred to a nitrocellulose membrane. The membranes were blocked for $1 \mathrm{~h}$ with $1 \%$ bovine serum albumin in PBST (137 mM NaCl, $10 \mathrm{mM}$ 
$\mathrm{Na}_{2} \mathrm{HPO}_{4}, 2.7 \mathrm{mM} \mathrm{KCl}, 1.4 \mathrm{mM} \mathrm{KH} \mathrm{PO}_{4}$, and $0.05 \%$ Tween 20) and then incubated with anti-phosphotyrosine (PY20) antibody $(1: 1,000)$ for $18 \mathrm{~h}$ at $4^{\circ} \mathrm{C}$. At the end of incubation, the membranes were washed and incubated with appropriate horseradish peroxidase-conjugated secondary antibodies (Amersham, Arlington Heights, IL; $1: 1,000$ dilution) for $1 \mathrm{~h}$ at room temperature. The membranes were then washed and exposed to the ECL detection system (Amersham). For the determination of Met, phospho-Met, Erk1/2, and phospho-Erk $1 / 2$, cell lysates (50-100 $\mu$ protein) were resolved on $8 \%$ SDS-PAGE, transferred onto nitrocellulose membranes, and immunoblotted with an antibody specific for the proteins to detect. The antiMet (C-28), -phospho-p44/p42 MAP Kinase, -p44/p42 MAP Kinase, and -tubulin antibodies were used at a concentration of $0.5 \mu \mathrm{g} / \mathrm{ml}$.

\section{Scratch wound motility assay}

SNU-484 cells were seeded into 24 -well plates $(2 \times$ $10^{5}$ cells/well) in RPMI-1640 supplemented with $10 \%$ FBS and allowed to adhere overnight. Cells were then starved with $0.1 \%$ FBS with or without $1 \mu \mathrm{g} / \mathrm{ml}$ of neutralizing anti-HGF antibody for $24 \mathrm{~h}$. The monolayers were then carefully scratched with sterile pipette tips and incubated with $0.1 \%$ serum-containing medium with $100 \mathrm{U} / \mathrm{ml}$ of rhHGF in the absence or presence of $1 \mu \mathrm{g} / \mathrm{ml}$ of neutralizing anti-HGF antibody for $72 \mathrm{~h}$. After washing three times with cold PBS, the cells were fixed in acetone: methanol $(1: 1, \mathrm{v} / \mathrm{v})$ for $15 \mathrm{~min}$ on ice and stained with $2 \%$ crystal violet.

\section{Results}

\section{Secretion of functional HGF by gastric cancer cells}

To address whether any gastric cancer cell line secretes HGF, each conditioned medium from 11 gastric carcinoma cell lines (AGS, SNU-1, SNU-5, SNU216, SNU-484, SNU-520, SNU-601, SNU-620, SNU638, SNU-668, and SNU-719) was subjected to ELISA assay. All cell lines except AGS were established from Korean patients by Korean Cell Line Bank (Park et al., 1997). Among the cell lines tested, only SNU484 cells were found to secrete a significant amount of HGF (about $1.25 \pm 0.41 \mathrm{ng} / 24 \mathrm{~h} / 10^{6}$ cells) into medium (data not shown). However, RT-PCR analysis revealed that mRNA transcript for HGF was also detected in two other cell lines, SNU-638 and SNU668 , and that the mRNA expression level of SNU-638 was similar to that of SNU-484 (Figure 1), showing disparity between HGF mRNA and protein expression. To examine whether the HGF released from SNU-484 was functional, the conditioned medium from each cell line was subjected to MDCK cell scattering assay: HGF is well known to dissociate the MDCK cell colonies and scatter the cells. As expected, MDCK cell colonies were scattered by the treatment with SNU-484 conditioned medium (Figure 2). However,

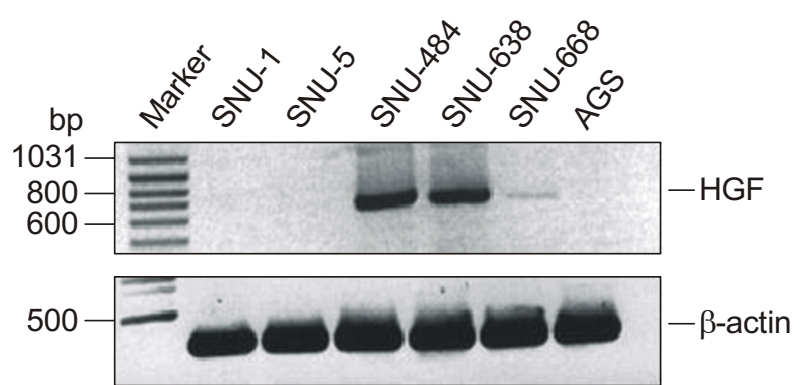

Figure 1. Expression of HGF mRNA in human gastric cancer cell lines. Total RNA from each gastric cancer cell line was extracted and used in RT-PCR. The PCR reaction was carried out for 30 cycles, and the reaction products were visualized by staining with ethidium bromide, as described in Materials and Methods. $\beta$-actin was amplified from the same samples as an assessment of the CDNA quantity used as template in the RT-PCR.

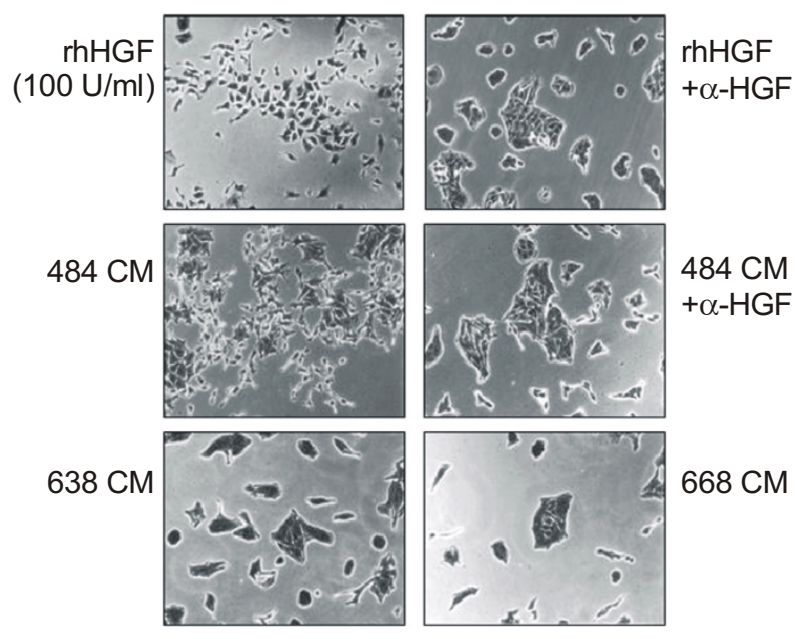

Figure 2. MDCK cell scattering induced by the conditioned media from gastric cancer cell lines. SNU-484, SNU-638, and SNU-668 cells were incubated in serum-free RMPI-1640 for $24 \mathrm{~h}$, and then the conditioned media (CM) were harvested. The conditioned media were concentrated 3 fold before being introduced into MDCK cells. rhHGF (100 units/ml) was used as a positive control for MDCK cell scattering. To neutralize the HGF effect on MDCK cell scattering, rhHGF or conditioned medium of SNU-484 cells were pre-incubated with neutralizing anti-HGF antibody $(1 \mu \mathrm{g} / \mathrm{ml})$ for $1 \mathrm{~h}$. After $24 \mathrm{~h}$, scattering was visually assessed under light microscope, and representative images were photographed.

the scattering was completely inhibited when the conditioned medium was pre-incubated with neutralizing anti-HGF antibody, indicating that the molecule in the medium to induce the scattering was HGF itself. Although mRNA transcript for HGF was also detected in SNU-638 and SNU-668 cells, neither of the conditioned media induced MDCK cell scattering, which was in accordance with the negative result obtained by ELISA. These results showed that there was no direct correlation between HGF mRNA and protein level, and that only SNU-484 cell line could secrete 


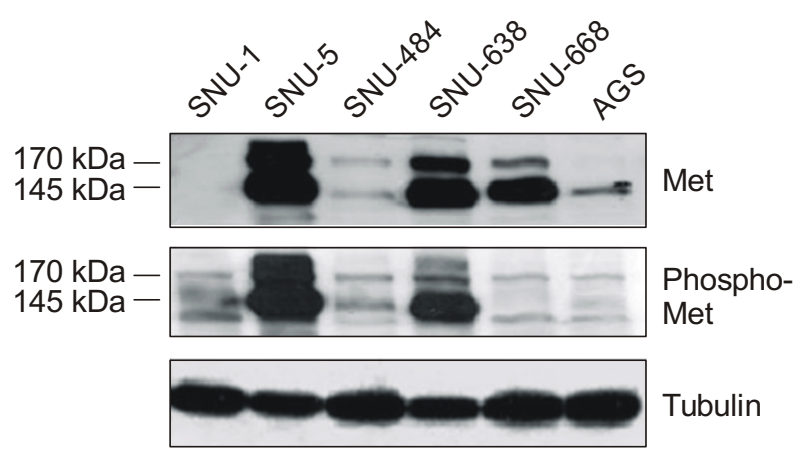

Figure 3. Met expression and status of Met activation in human gastric cancer cell lines. Each cell line was cultured to $80 \%$ confluence, serum-starved overnight, and lysed using RIPA buffer. Clarified cell lysates were normalized for protein concentration, subjected to SDS-PAGE and inmmunoblotted with anti-Met (upper panel) or anti-phospho-Met antibody (middle panel). Equal protein loading was confirmed with anti-tubulin antibody. Met was detected as two bands with different sizes; i.e., $170 \mathrm{kD}$ precursor form and $145 \mathrm{kD}$ mature form.

functional HGF into medium.

\section{Autocrine HGF-Met signaling in SNU-484 cell line}

Met expression in gastric carcinoma cell lines including SNU-484 was analyzed by Western blotting. Although the expression level of Met was varied greatly from cell line to cell line, all the cell lines, except SNU-1, expressed Met protein (Figure 3, upper panel). The level of Met in SNU-484 cells was relatively low among the cell lines tested, and much higher levels were detected in SNU-5, SNU-638, and SNU-668 cells. To examine the steady state of Met activation in each cell line, the blot was re-probed with phospho-Met antibody raised against pTyr1234/ 1235 because autocrine HGF-Met signaling would result in constitutive activation of Met. As expected, constitutive activation of Met was observed in SNU484 cells (Figure 3 , middle panel). Interestingly, the Met expressed in SNU-5 and SNU-638 was also highly phosphorylated, even though the HGF produced by these cells was negligible according to ELISA assay (data not shown) possibly due to the ligand-independent activation of Met via spontaneous dimerization and phosphorylation when overexpressed (Rusciano et al., 1996). To further demonstrate autocrine HGF-Met signaling in SNU-484 cells, Met in SNU-484 cells was immunoprecipitated and the degree of tyrosine phosphorylation was assessed. As expected, Met was found to be constitutively tyrosinephosphorylated as shown in Figure 4A. Tyrosine phosphorylation of Met was significantly reduced when neutralizing anti-HGF antibodies were added to the medium, strongly suggesting that the constitutive phosphorylation of Met was due to the presence of HGF in the medium. Subsequent addition of exogenous rhHGF could restore the decreased Met phosphorylation by neutralizing antibody, further streng-
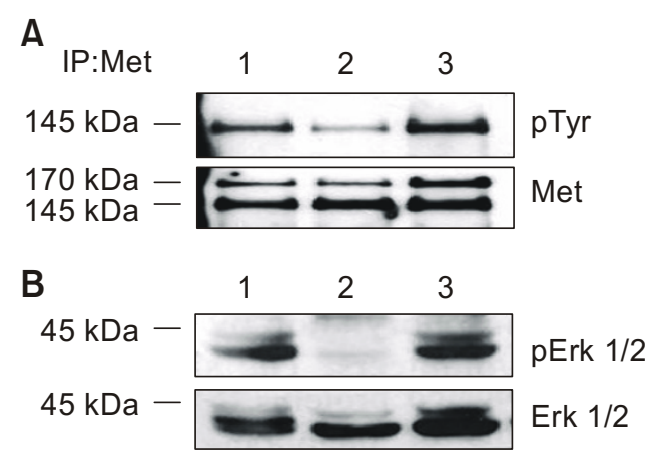

Figure 4. Autocrine phosphorylation of Met in SNU-484 cells. SNU484 cells were cultured to $80 \%$ confluence and further incubated in RPMI-1640 containing $0.1 \%$ FBS for $24 \mathrm{~h}$ without (lane 1) or with $1 \mu \mathrm{g} / \mathrm{ml}$ of neutralizing anti-HGF antibody (lanes 2 and 3). Met was immunoprecipitated from the cells after without (lanes 1 and 2) or with additional incubation for 10 min with 100 units/ml of rhHGF (lane 3). Each immunoprecipitate was subjected to SDS-PAGE and Western blotting. The blot was probed with anti-phosphotyrosine (PY20) antibody. The same blot was stripped and re-probed with anti-Met antibody as a loading control (A, lower panel). The lysates from (A) were subjected to SDS-PAGE, immunoblotted with anti-phospho-p44/p42 MAP kinase antibody ( $B$, upper panel) and re-probed with anti-p44/p42 MAP kinase antibody ( $B$, lower panel).

thening the causative role for HGF in the constitutive tyrosine phosphorylation of Met in these cells (Figure $4 \mathrm{~A}$, lane 3 ). The decrease of tyrosine phosphorylation in the neutralizing antibody-treated sample was not due to a general down-regulation of the amount of the receptor protein as shown in Figure 4A, lower panel. These results demonstrated that SNU-484 could not only produce HGF, but also respond to the HGF through its receptor, Met, indicating the existence of an autocrine HGF-Met signaling in this cell line.

Activation of the Ras-Erk MAP kinase pathway is one of the main downstream signaling pathways of HGF/Met, required for HGF-induced adherens junction disassembly, cell motility, proliferation and tubulogenesis (Maroun et al., 2000; Schaeper et al., 2000). As shown in Figure 4B, Erk1/2 in SNU-484 cells was phosphorylated without exogenous rhHGF treatment, and Erk1/2 protein phosphorylation was reduced in the presence of neutralizing anti-HGF antibody.

\section{Effects of HGF-Met autocrine signaling on cell proliferation and migration}

HGF-Met signaling has been documented in various carcinomas to play a role in the development and dissemination of this class of tumors. To determine if autocrine HGF-Met signaling in SNU-484 could exert mitogenic effect, cell growth was examined by MTT assay. As shown in Figure $5 \mathrm{~A}$, cell growth was dose-dependently inhibited when the autocrine HGF activity was blocked by neutralizing antibody. One $\mu \mathrm{g} / \mathrm{ml}$ of anti-HGF antibody began to significantly inhibit the cell growth $48 \mathrm{~h}$ after neutralization, which was expected since Erk $1 / 2$ protein phosphorylation, 


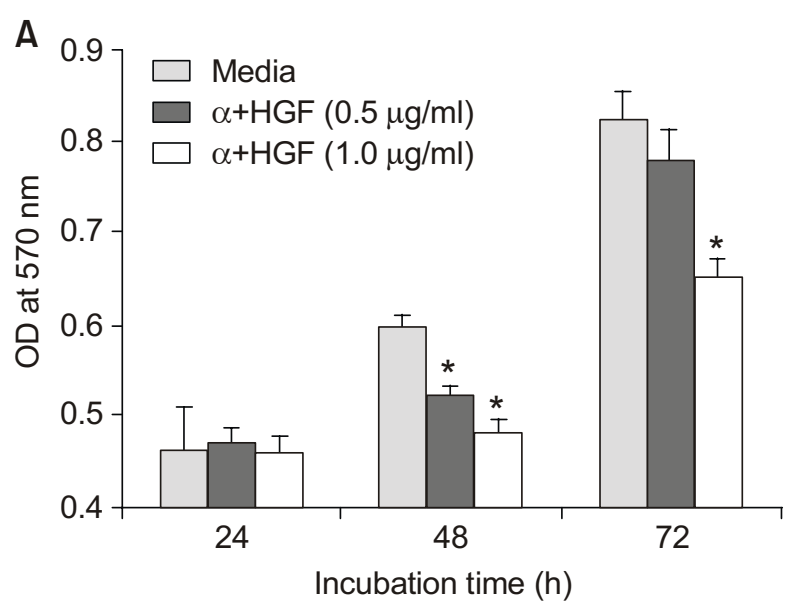

B

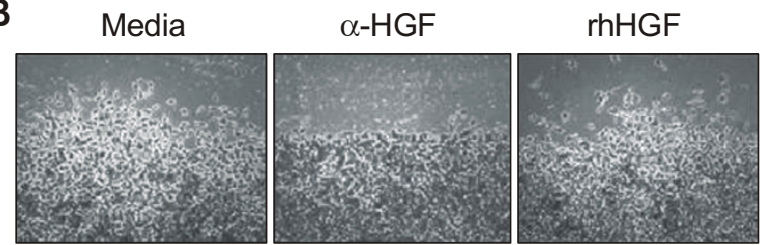

Figure 5. Effect of autocirne HGF-Met signaling on SNU-484 cell proliferation (A) and migration (B). (A) SNU-484 cells were plated in 96-well plates $\left(1 \times 10^{4}\right.$ cells/well) and cultured overnight. The cells were treated with different amounts of neutralizing anti-HGF antibody in RPMI-1640 containing $0.1 \%$ FBS, and MTT assay was performed at every $24 \mathrm{~h}$. Mean values of O.D. at $570 \mathrm{~nm}$ from triplicate experiments are presented. "denotes statistically significant difference $(P<0.05)$ compared to mean value of media-only group at the same time point by student's t-test. Error bar represents standard deviation. (B) SNU-484 cells were cultured to $90 \%$ confluence, and a scratch (physical wound) was made in the cell layer. The cells were incubated with media in the presence of neutralizing anti-HGF antibody (1 $\mu \mathrm{g} / \mathrm{ml})$, or rhHGF $(100 \mathrm{U} / \mathrm{ml})$ for $72 \mathrm{~h}$. The migration of cells at the wound edge (arrow) was observed under a phase-contrast microscope $(\times 100)$ after staining with crystal violet, as described in Materials and Methods.

which is known to be involved in HGF-induced cell proliferation, was reduced in the presence of neutralizing anti-HGF antibody (Figure 4B). These results indicate that autocrine HGF signaling affects the proliferation of SNU484 cells positively.

By using scratch wound motility assay, we also examined whether the autocrine HGF-Met signaling had any influence on SNU-484 cell migration. In scratch wounds of confluent cultures, both exogenous and endogenous HGF markedly stimulated the migration and scattering of SNU-484 cells into the wound area, compared with the cells cultured in the presence of neutralizing anti-HGF antibody (Figure $5 B)$. Therefore, autocrine HGF-Met signaling in SNU484 cells seemed to affect not only cell proliferation, but also migration, thus suggesting possible involvement of HGF-Met autocrine signaling in both tumorigenesis and progression of stomach cancer.

\section{Discussion}

In the present study, we demonstrated the presence of autocrine HGF-Met signaling in a gastric cancer cell line, SNU-484. SNU-484 cancer cells produced and secreted functional HGF into its medium. And the secreted HGF could bind to Met and induced downstream signaling in these cells. We showed that Met autophosphorylation, Erk1/2 activation, and cell proliferation were inhibited by specific neutralizing antiHGF antibodies, suggesting that autocrine HGF-Met signaling is important for normal growth of SNU-484 cells. In addition, cell migration after scratch wound was dramatically reduced in the presence of anti-HGF antibody, evidencing that HGF-Met autocrine signaling plays an important role in the migration of SNU-484 cells.

Paracrine activation of HGF-Met signaling via overexpression of HGF and/or Met has been well known in many carcinomas (Furukawa et al., 1995; Tamatani et al., 1999); whereas HGF-Met autocrine signaling has been considered to contribute to the tumorigenic process mainly in human sarcomas. Human osteosarcoma cell lines as well as fibroblast cell lines or tumors from Li-Fraumeni patients have been reported to express high levels of Met, enabling autocrine HGF-Met signaling to operate. Interestingly, as in the case of Li-Fraumeni patients, the loss of p53 enhances the expression of Met in mesenchymal cells, and this expression is regarded as one of important steps in sarcomagenesis observed frequently in the syndrome (Cortner et al., 1995; Rong et al., 1995).

Although mutational analyses for several tumor suppressor genes and oncogenes have been carried out, the molecular mechanisms underlying gastric carcinoma development have not yet been clearly defined. In recent years, much work has demonstrated that abnormal HGF-Met signaling is associated with the tumorigenesis of gastric cancer. In general, the abnormal HGF-Met signaling is known to arise from 1) overexpression of HGF and/or Met, 2) missense mutation in tyrosine kinase domain and juxtamembrane region of Met, and 3) co-expression of HGF and Met. Met has been shown to be overexpressed in several human gastric carcinoma cell lines, and constitutive activation of Met was observed in GTL-16 cells (Ponzetto et al., 1991; Faletto et al., 1992). GTL-16 cells overexpressed Met as a consequence of gene amplification and the constitutive activation was HGF-independent. Similarly, we observed that abundantly expressed Met in SNU-5 and SNU-638 was constitutively autophosphorylated without exogenous HGF treatment or autocrine HGF stimulation. Rusciano et al. suggested that the ligandindependent activation observed in the B16-LS9 cells was caused by the high number of receptors present on the cell surface, leading to spontaneous dimerization and phosphorylation (Rusciano et al., 1996). Consistent with these findings, the ligand-independent activation of Met was observed only in cell lines where Met was overexpressed (Ponzetto et al., 1991). 
It is now well accepted that overexpression of the receptor itself leads to constitutive activation of the receptor proteins. There might be another way to explain the constitutive activation of Met observed in SNU638 cell line. As suggested previously, HGF and Met may be co-secreted into some double-membrane bound structure that never leaves the cytoplasm (Wilson et al., 1993; Qiao et al., 2002). In this intracrine manner, Met can be constitutively activated by HGF while HGF is not detected in the culture supernatant.

Genetic analysis of human papillary renal carcinomas indicated that activating missense mutations in the met gene, which was found to be confined in tyrosine kinase domain, were causative in inherited and some sporadic papillary renal carcinomas (Schmidt et al., 1997). Whereas no mutation in the tyrosine kinase domain has been detected in primary gastric carcinomas or gastric cancer cell lines (Park et al., 2000; Yokozaki et al., 2000; Kim et al., 2003), two mutations in other parts of met have been identified in gastric cancer patients. One of them is a P1009s mutation, which was localized in the juxtamembrane domain (Lee et al., 2000) and showed transforming activity in nude mice. The other is a P791L mutation localized in the extracellular domain (Kim et al., 2003). Since the frequency of the mutation was quite low in both studies, it is obvious that Met mutation does not seem to play a major role in the development of gastric cancer unlike in papillary renal carcinomas.

Inappropriate or ectopic expression of Met in NIH3T3 cells, which express HGF endogenously, led to tumorigenesis through an autocrine mechanism (Rong et al., 1992; Rong et al., 1994) and much works demonstrated that HGF-Met autocrine signaling is closely related with malignant progression of tumor cells. Indeed, coexpression of HGF and Met has been detected in a variety of human tumors (Jin et al., 1997; Ebert et al., 1999; Wong et al., 2001). Park et al. screened 43 primary gastric carcinomas immunohistochemically and found that 13 out of total showed both HGF and Met signals in tumor cells (Park et al., 2000), suggesting the presence of HGFMet autocrine signaling in gastric cancer. However, it cannot rule out the possibility that the HGF protein detected in tumor cells was originated from neighboring fibroblasts. Fushida and co-workers earlier examined the expression of HGF and Met mRNA in seven gastric cancer cell lines, and demonstrated that MKN-45 cells expressed both (Fushida et al., 1993). Although they suggested the presence of HGF-Met autocrine loop in gastric cancer, they failed to demonstrate either whether HGF from the cell actually stimulated Met or whether the autocrine signaling has a physiological meaning in this cell line. Furthermore, Yokozaki showed a controversial observation that HGF mRNA was undetectable in MKN-45 cells (Yokozaki, 2000). In the present study, we clearly demonstrated that SNU-484 gastric cancer cells produced and secreted functional HGF, resulting in an autocrine signaling, which helped these cells to proliferate and migrate. Since only SNU-484 cell line among the 11 cell lines screened showed HGF-Met autocrine signaling, HGF-Met autocrine signaling does not seem to play a major role in gastric carcinogenesis. Nevertheless, it is highly suggestive that HGF-Met autocrine signaling may contribute to the development and progression of gastric carcinoma.

\section{Acknowledgement}

This work was supported by a grant of Korea Science and Engineering Foundation through Chronic Inflammatory Disease Research Center (R13-2003-019).

\section{References}

Bottaro DP, Rubin JS, Faletto DL, Chan AM, Kmiecik TE, Vande Woude GF, Aaronson SA. Identification of the hepatocyte growth factor receptor as the c-met proto-oncogene product. Science 1991;251:802-4

Cortner J, Vande Woude GF, Rong S. The Met-HGF/SF autocrine signaling mechanism is involved in sarcomagenesis. EXS 1995;74:89-121

Di Renzo MF, Narsimhan RP, Olivero M, Bretti S, Giordano S, Medico E, Gaglia P, Zara P, Comoglio PM. Expression of the Met/HGF receptor in normal and neoplastic human tissues, Oncogene 1991;6:1997-2003

Ebert M, Yokoyama M, Ishiwata T, Friess H, Buchler MW, Malfertheiner $\mathrm{P}$, Korc $M$. Alteration of fibroblast growth factor and receptor expression after acute pancreatitis in humans. Pancreas 1999;18:240-6

Faletto DL, Tsarfaty I, Kmiecik TE, Gonzatti M, Suzuki T, Vande Woude GF. Evidence for non-covalent clusters of the c-met proto-oncogene product. Oncogene 1992;7:1149-57

Furukawa T, Duguid WP, Kobari M, Matsuno S, Tsao MS. Hepatocyte growth factor and Met receptor expression in human pancreatic carcinogenesis. Am J Pathol 1995;147: 889-95

Fushida S, Yonemura Y, Urano T, Yamaguchi A, Miyazaki I, Nakamura T, Shiku H. Expression of hepatocyte growth factor(HGF) and c-met gene in human gastric cancer cell lines. Int J Oncol 1993;3:1067-70

Han SU, Joo HJ, Lee JH, Kim WH, Cho YK, Kim MW. Role of Hepatocyte growth factor, Met and E-cadherin in the progression of gastric carcinoma. J Korean Surg Soc 1998; 55:53-64

Han SU, Lee JH, Kim WH, Cho YK, Kim MW. Significant correlation between serum level of hepatocyte growth factor and progression of gastric carcinoma. World J Surg 1999; 23:1176-80

Jin L, Fuchs A, Schmitt SJ, Yao Y, Joseph A, Lamszus K, Park M, Goldberg ID, Rosen EM. Expression of scatter factor and c-met receptor in benign and malignant breast tissue. Cancer 1997;79:749-60

Kaji M, Yonemura Y, Harada S, Liu X, Terada I, Yamamoto $\mathrm{H}$. Participation of $\mathrm{C}$-met in the progression of human gastric 
cancers: anti-c-met oligonucleotides inhibit proliferation or invasiveness of gastric cancer cells. Cancer Gene Ther 1996;3:393-404

Kim IJ, Park JH, Kang HC, Shin Y, Lim SB, Ku JL, Yang $\mathrm{HK}$, Lee KU, Park JG. A novel germline mutation in the MET extracellular domain in a Korean patient with the diffuse type of familial gastric cancer. J Med Genet 2003:40:e97

Lee JH, Han SU, Cho H, Jennings B, Gerrard B, Dean M, Schmidt L, Zbar B, Vande Woude GF. A novel germ line juxtamembrane Met mutation in human gastric cancer. Oncogene 2000;19:4947-53

Maroun CR, Naujokas MA, Holgado-Madruga M, Wong AJ, Park M. The tyrosine phosphatase SHP-2 is required for sustained activation of extracellular signal-regulated kinase and epithelial morphogenesis downstream from the met receptor tyrosine kinase. Mol Cell Biol 2000;20:8513-25

Otsuka T, Takayama H, Sharp R, Celli G, LaRochelle WJ, Bottaro DP, Ellmore L, Vieira W,. Owens JW, Anver M, Merlino G.. c-Met autocrine activation induces development of malignant melanoma and acquisition of the metastatic phenotype. Cancer Res 1998;58:5157-67

Park JG, Yang HK, Kim WH, Chung JK, Bang YJ, Kim YI, Kim JP. Establishment and characterization of human gastric carcinoma cell lines. Int J Cancer 1997;70:443-9

Park WS, Oh RR, Kim YS, Park JY, Shin MS, Lee HK, Lee $\mathrm{SH}$, Yoo NJ, Lee JY. Absence of mutations in the kinase domain of the Met gene and frequent expression of Met and HGF/SF protein in primary gastric carcinomas. APMIS 2000; 108:195-200

Ponzetto C, Giordano S, Peverali F, Della Valle G, Abate $M L$, Vaula G, Comoglio PM. c-met is amplified but not mutated in a cell line with an activated met tyrosine kinase. Oncogene 1991;6:553-9

Qiao H, Hung W, Tremblay E, Wojcik J, Gui J, Ho J, Klassen $\mathrm{J}$, Campling B, Elliott B. Constitutive activation of met kinase in non-small cell lung carcinomas correlates with anchorageindependent cell survival. J Cell Biochem 2002;86:665-77

Rong S, Bodescot M, Blair D, Dunn J, Nakamura T, Mizuno K, Park M, Chan A, Aaronson S, Vande Woude GF. Tumorigenicity of the met proto-oncogene and the gene for hepatocyte growth factor. Mol Cell Biol 1992;12:5152-8

Rong S, Segal S, Anver M, Resau JH, Vande Woude GF. Invasiveness and metastasis of NIH 3 T3 cells induced by Met-hepatocyte growth factor/scatter factor autocrine stimulation. Proc Natl Acad Sci USA 1994;91:4731-5

Rong S, Donehower LA, Hansen MF, Strong L, Tainsky M, Jeffers M, Resau JH, Hudson E, Tsarfaty I, Vande Woude GF. Met proto-oncogene product is overexpressed in tumors of p53-deficient mice and tumors of Li-Fraumeni patients. Cancer Res 1995;55:1963-70

Rosen EM, Nigam SK, Goldberg ID. Scatter factor and the c-met receptor: a paradigm for mesenchymal/epithelial interaction. J Cell Biol 1994;127:1783-7

Rubin JS, Chan AM, Bottaro DP, Burgess MH, Taylor WG, Cech AV, Hirschfield DW, Wong J, Miki T, Finch PW, Aaronson SA. A broad-spectrum human lung fibroblastderived mitogen is a variant of hepatocyte growth factor. Proc Natl Acad Sci USA 1991;88:415-9

Rusciano $D$, Lorenzoni $P$, Burger MM. Constitutive activation of c-Met in liver metastatic B16 melanoma cells depends on both substrate adhesion and cell density and is regulated by a cytosolic tyrosine phosphatase activity. J Biol Chem 1996;271:20763-9

Schaeper U, Gehring NH, Fuchs KP, Sachs M, Kempkes $\mathrm{B}$, Birchmeier W. Coupling of Gab1 to c-Met, Grb2, and Shp2 mediates biological responses. J Cell Biol 2000;149: 1419-32

Schmidt L, Duh FM, Chen F, Kishida T, Glenn G, Choyke $P$, Scherer SW, Zhuang Z, Lubensky I, Dean M, Allikmets R, Zwar B. Germline and somatic mutations in the tyrosine kinase domain of the MET proto-oncogene in papillary renal carcinomas. Nat Genet 1997;16:68-73

Shiota G, Kawasaki H, Nakamura T. Coexpression of hepatocyte growth factor and its receptor (c-met oncogene) in HGL4 glioblastoma cells. Oncology 1996;53:511-6

Stella MC, Comoglio PM. HGF: a multifunctional growth factor controlling cell scattering. Int J Biochem Cell Biol 1999; $31: 1357-62$

Stoker M, Perryman M. An epithelial factor released by embryo fibroblasts. J Cell Sci 1985;77:209-23

Tamatani T, Hattori K, lyer A, Tamatani K, Oyasu R. Hepatocyte growth factor is an invasion/migration factor of rat urothelial carcinoma cells in vitro. Carcinogenesis 1999; 20: 957-62

Wilson SE, Walker JW, Chwang EL, He YG. Hepatocyte growth factor, keratinocyte growth factor, their receptors, fibroblast growth factor receptor-2, and the cells of the cornea. Invest Ophthalmol Vis Sci 1993;34:2544-61

Wong AS, Pelech SL, Woo MM, Yim G, Rosen B, Ehlen $T$, Leung PC, Auersperg A. Coexpression of hepatocyte growth factor-Met: an early step in ovarian carcinogenesis? Oncogene 2001;20:1318-28

Yokozaki H. Molecular characteristics of eight gastric cancer cell lines established in Japan. Pathol Int 2000;50:767-77 